\title{
A varrattechnika fejlődése a kéz hajlítóín-sérüiléseiben az elmúlt tizenöt esztendő során
}

\author{
Bíró Vilmos dr.
}

\begin{abstract}
A kéz hajlítóín-sérüléseinek helyreállításában alapvető jelentőségű az optimális varratforma megválasztása, amely lehetôvé teszi a korai, aktív posztoperatív mobilizáció mielőbbi megkezdését és ezzel a lehető legjobb végeredmények elérését. A szerző irodalmi elemző tanulmányában áttekinti az elmúlt tizenöt esztendőben történt fejlődést a hajlítóín-sérülések varrattechnikájában és az ezzel elért eredményeket a kísérletes ínhelyreállításban, továbbá a klinikai végeredményekben. A különböző, újabb varratféleségek kivitelezésének leírása mellett tárgyalja az ujjak gyürüszalagrendszerének, az ínvarratoknak az ínvégek közötti feszülésének, valamint a helyreállított ín mozgásirányának jelentőségét. Befejezésül megállapítja, hogy a tárgyalt, korszerú ínvarratok minél szélesebb körű alkalmazása szükséges a jobb mütét utáni végeredmény eléréséhez. Orv. Hetil., 2016, 157(6), 212-218.
\end{abstract}

Kulcsszavak: hajlítóínvarratok a kézen, újabb varrattípusok, szakítószilárdság, gyưrűszalagok, aktív mobilizáció

\section{Developments in suture techniques of hand flexor tendon injuries during the last fifteen years}

In the reconstruction of hand flexor tendon injuries it is fundamental to select the best suture technique, which makes possible early, active postoperative mobilization and achievement of the best results. The author reviews the development of suture techniques of the flexor tendon injuries during the last fifteen years, and discusses experimental tendon reconstruction results as well as clinical outcomes. The author describes the importance of different tendon suture materials, the significance of the pulley system of the fingers, the stretching between the sutured tendon ends by tendon sutures and, finally, the importance of the moving course in the reconstructed tendon. He states, that the wide-range adoption of the discussed modern tendon sutures would be necessary for better postoperative results.

Keywords: flexor tendon sutures in the hand, novel suture techniques, tensile strength, pulleys, active mobilization

Bíró, $V$. [Developments in suture techniques of hand flexor tendon injuries during the last fifteen years]. Orv. Hetil., $2016,157(6), 212-218$.

(Beérkezett: 2015. november 10.; elfogadva: 2015. december 5.)

Az orvostudomány elméleti, illetve gyakorlati ismeretanyagának felgyorsulása az elmúlt tizenöt esztendőben különösen intenzívvé vált. Nem kivétel ez alól az operatív klinikai tudományok, így a kézsebészet mütétes területeinek rohamos fejlődése sem. A helyreállító kézsebészet egyik legnehezebb feladatát képezi a sérült hajlítóinak mútéti rekonstrukciója, mivel a funkcionális végeredmények nagyrészt csak kielégítőnek vagy legfeljebb elfogadhatónak bizonyultak, még a legjobb mütéti technika és utókezelés mellett is. Így nem véletlen, hogy hosszú ideje folynak kísérletes és klinikai vizsgálatok az eredmények javítása érdekében. E kérdéskörrel magyar kutatók is - a teljesség igénye nélkül felsorolt - több közleményben [1-5] foglalkoztak, míg a külföldi, neves kézsebészeti folyóiratokban publikált dolgozatok száma szinte áttekinthetetlenül nagy; az általunk fontosabbnak ítélt munkákat e cikk Irodalomjegyzékében tüntettük fel.

A hajlítóín-sérülések esetében a primer, illetve a másodlagos ínvarratok a mútéti kezelés legfontosabb elemeinek tekinthetők. Így érthető, hogy az e kérdéssel foglalkozó nagyszámú szerző számos ínvarratfajtát dolgozott ki, amelyek - reményeik szerint - lehetővé tették, hogy a jelenleg legkorszerúbbnek tartott posztoperatív 


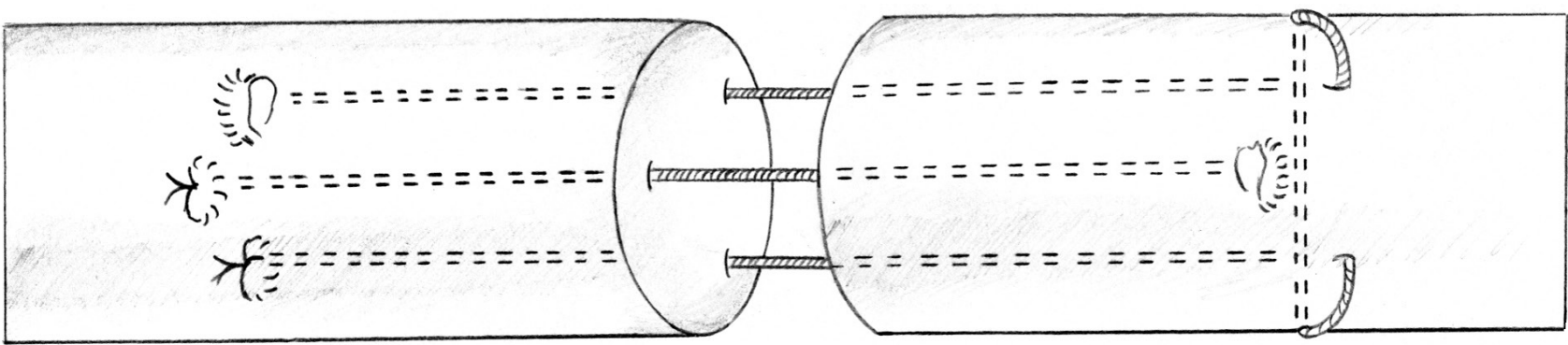

1. ábra

| Wang és mtsai [7] által használt korszerú, több öltésből álló hajlítóínvarrat vázlatos rajza ( Wu és Tang [6] ábrája nyomán)

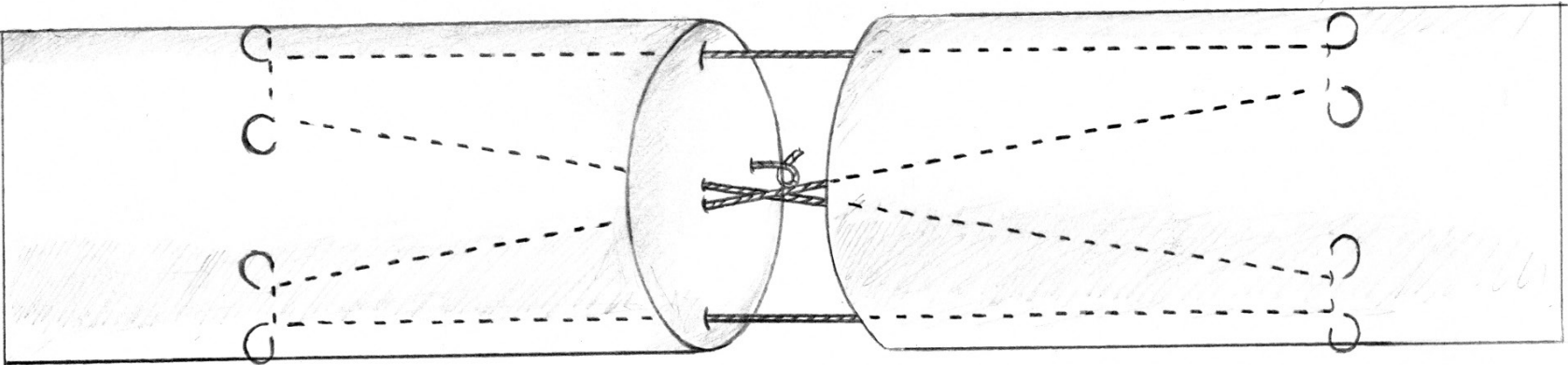

\begin{tabular}{l|l} 
2. ábra & $\begin{array}{l}\text { Az úgynevezett Lahey-módszer. E varrattípust Manchio és mtsai [9] dolgozták ki és jó klinikai eredményeket közöltek használatával ( Wu és Tang [6] } \\
\text { ábrája után) }\end{array}$
\end{tabular}

rehabilitációs kezelést, a korai, aktív mobilizációt végezhessék a legjobb eredmény érdekében.

Dolgozatunkban e kérdést kívántuk vizsgálat tárgyává tenni, felhasználva és értékelve a legfrissebb szakirodalmi adatokat. Az újabb varrattechnikákról és az elért eredményekről Wu és Tang (2014) [6] közöltek nemrégiben igen részletes irodalmi, elemző közleményt, amelyet publikációnk megírásához fontos segédanyagként használtunk fel.

A varrott ín szakítószilárdságának növelése jelenleg is a kézsebészek alapvető célja, hogy csökkenthető legyen a sebészileg helyreállított inak szakadása. Az ínhelyreállítás kudarcát ugyanis a legtöbb esetben az ínvégek között, a mozgatás hatására kialakult rés (gap) okozta ínruptura jelenti. Az elmúlt tizenöt évben jelentős változásoknak lehettünk tanúi: egyre több szerző használja a többszörös öltésből álló különböző ínvarratokat, és ma már ezek széles körü használatának lehetünk tanúi. Mindezek valószínúleg a legfontosabb fejlődést jelentik az ínsebészetben [6].

\section{Ínvarrattípusok}

A 4 vagy 6 varrószálból álló ínvarratot az 1980-as és az 1990-es években fejlesztették ki, e módszerek többségében azonban az egyszerúsítésre való törekvést figyelhettük meg. Wang és mtsai [7] módosították az eredeti, 6 öltéses Tang-módszert [8], a varrathoz egy harántöltést hozzáadva, így egy „M” konfigurációt formálva az öltéssel, amely kevesebb öltést és csomót jelentett az ín felszínén (1. ábra). Kutatók másik csoportja ugyanakkor újabb varratformákat fejlesztett ki annak érdekében, hogy csökkentsék az ínvégek között, a mozgatás hatására kialakult résképződést. Ezen varratféleségek között található a Labey-féle módszer [9] (2. ábra). Bár számos egyéb varrattechnikát ismertettek, amelyek kielégítő szakítószilárdsággal rendelkeztek a helyreállított ín korai, posztoperatív mozgatásának elviseléséhez, nagyobb részük azonban túlzottan bonyolult volt a sebészi felhasználás céljaira, az emberi hajlítóinak viszonylag kis átmérője miatt. Ráadásul a nagy szakítószilárdságú varrat rendszerint vaskos, nagy ellenállással rendelkező helyreállított területet jelentett, amely jelentősen korlátozta az ín elcsúszási folyamatát. A 2. zónában létrejött hajlítóínsérülések több öltéssel rendelkező varrattechnikájáról számos közleményben ismertettek kitűnő végeredmé-

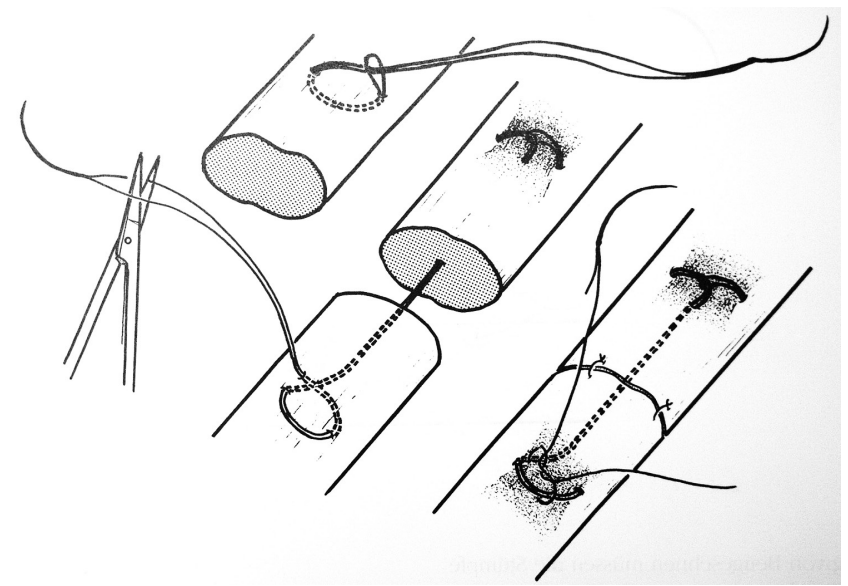

3. ábra $\quad$ A régebben alkalmazott, Tsuge-féle ínvarrat vázlatos rajza [3] 


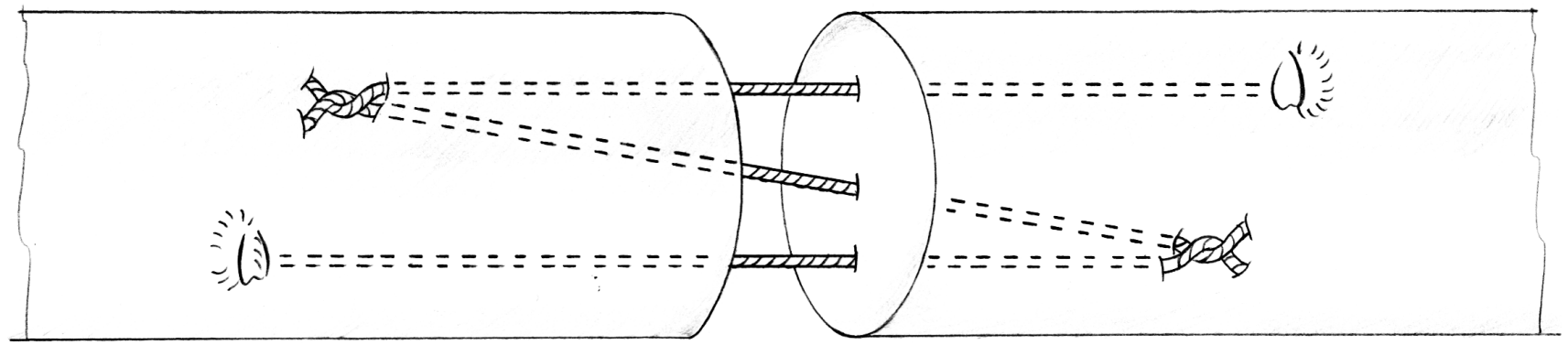

4. ábra

| Hoffmann és mtsai [11] fejlesztették ki ezt a varratot, amellyel kifejezetten jó funkcionális eredményeket értek el

nyeket [6]. Igy Osada és mtsai [10] 27 ujjon végeztek hajlítóín-helyreállítást háromöltéses varrattal, amelyet korai, aktív mobilizáció követett. A helyreállított inak 96\%-ában értek el jó vagy kitűnő eredményt, és nem találtak ínrupturát.

A fenti varrattechnikák közös eleme a Tsuge-varrat [3], amely kellően erős és könnyü kivitelezni (3. ábra). A 6 szálból álló Lim-Tsai-módszerról (4. ábra), amely a Tsuge-varrat egy részét is magában foglalja, közölték, hogy jobb átlagos csúcsfogási erő érhető el vele; a varrott ujjon szignifikánsan nagyobb teljes, aktív mozgást, alacsonyabb szövődményrátát és a kezelés rövidebb átlagos időtartamát találták, összehasonlítva a kétszálas Kessler(5-7. ábra) technikával $[3,11]$.

A Teno Fix eszköz (Ortheon Medical, Winter Park, FL, Amerikai Egyesült Államok) újabb és egyedülálló próbálkozás hajlítóínvarratokhoz (www.biomath.info/ Protocols/Duke/docs/ChenLan.pdf). Bár a kezdeti klinikai tapasztalatok kedvezőek voltak, és a termék kivitelezése alapos, e módszer nem vált népszerúvé. Az eszköz két, intratendinealis, rozsdamentes acélból álló horgonynyal rendelkezik, amely összeköttetésben áll egy multifil 2-0-s, rozsdamentes acél varróanyaggal (8. ábra). In vitro és in vivo tanulmányok jó eredményeket mutattak a Teno Fixszel történt helyreállítással [12-14]. Klinikai
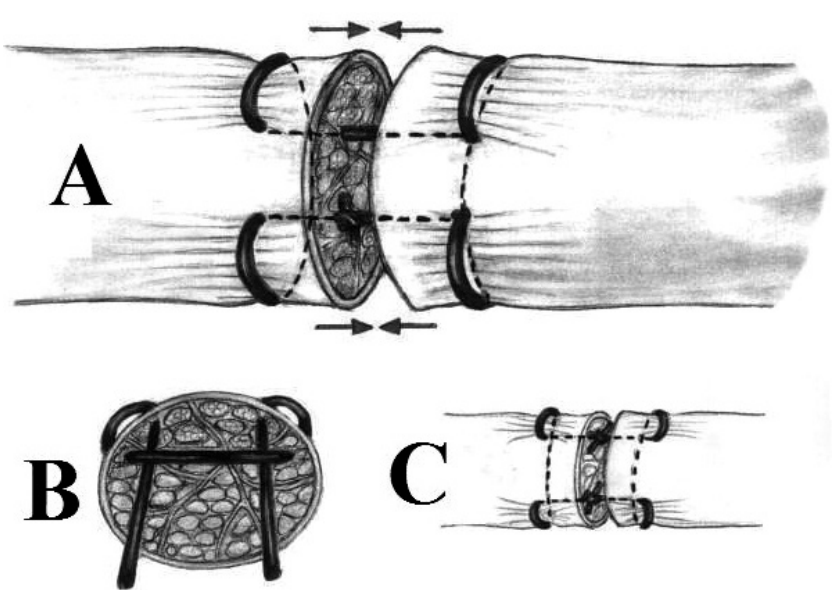

5. ábra

A hagyományos Kessler-féle intratendinealis varrat sémás ábrázolása. A) Az egycsomós varrat elhelyezkedése az öltések meghúzása előtt. B) Az ín harántmetszetében az öltések helye C) A kétcsomós ínvarrat [3] vizsgálatok szerint az ínvarratok alacsonyabb rupturaszámot és hasonló funkcionális eredményeket mutattak a 4 szálas, keresztezett ínvarrattechnikához viszonyítva [15, 16]. A Teno Fix ínvarró eszköz - úgy tünik - erősebb ínvarratot eredményez, amely korai, aktív ujjmozgatást és gyorsabb funkcionális felépülést tesz lehetővé. Mind-

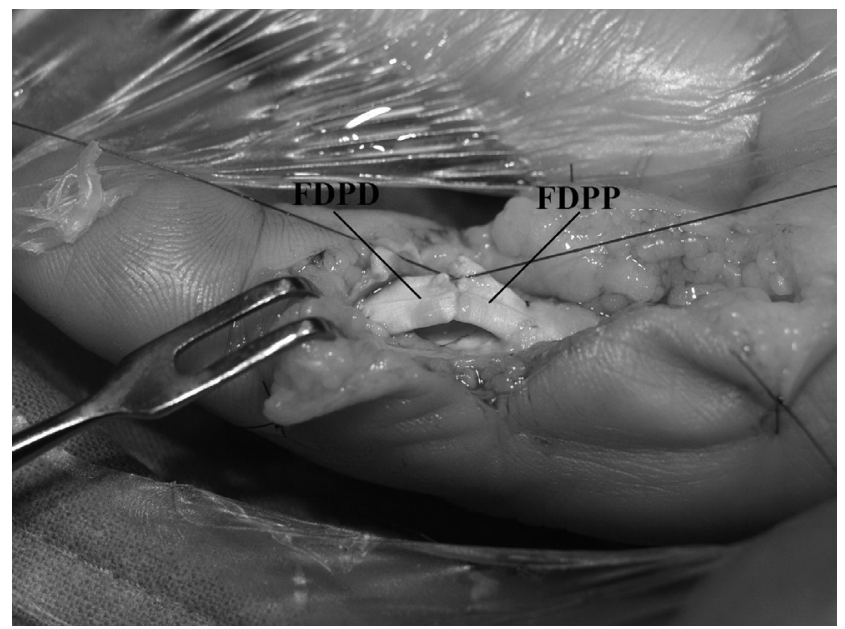

6. ábra | Mútéti kép. Az elkészült Kessler-varrat, megcsomózás előtt

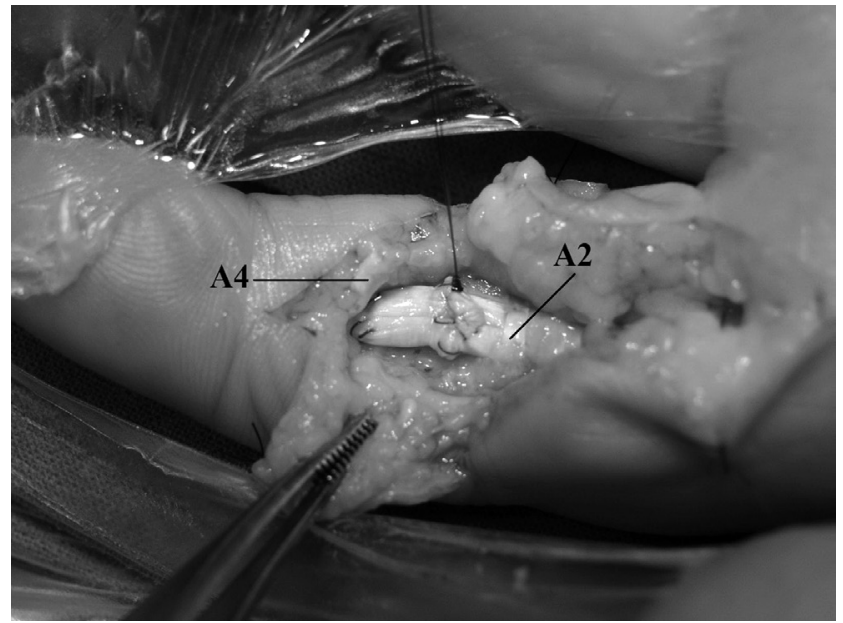

7. ábra

Az intratendinealis és a cirkuláris varratok: a végleges ínvarrat elkészült. A2 és A4 a gyürűszalagok jelölése. (A mútétet $D r$. Molnár László végezte, a fotókat a szerző készítette) 


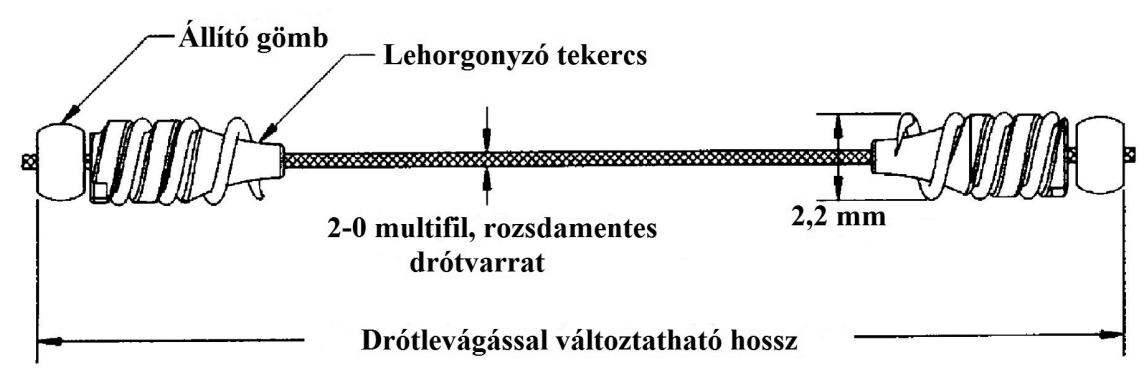

8. ábra

| A Teno Fix eszköz vázlatos rajza. Ábramagyarázat a szövegben

azonáltal használata nem javasolt kis átmérőjü inaknál és ha a feltárás nem megfelelő, vagy szennyezett, komplex, többszörös ínsérüléseknél, továbbá felrostozódott ínvégeknél. A klinikai felhasználásban nagyobb gondot jelent a varratot követően az ín átmérőjének megvastagodása a gyürüszalagok területén és az, hogy egy második műtéttel el kell távolítani az eszközt. Ezek a potenciális hátrányok képezik a legfőbb akadályát az eszköz elterjedésének [6].

\section{A gyürüszalagok jelentősége}

Az elmúlt évek során a kutatások egyik fontos kérdése volt, hogy a jelentősebb $\left(\mathrm{A}_{2}\right.$ és $\left.\mathrm{A}_{4}\right)$ pulley-k sebészi helyreállítása hogyan befolyásolja a varrott ín gyógyulási végeredményét. Állatokon, illetve cadavereken végzett kísérleteknél, amelyeknél kimetszették a superficialis ín mindkét szárát és ugyanakkor megvarrták a profundus ín lacerált átmetszését, az $\mathrm{A}_{2}$ pulley-n belül csökkent ellenállást találtak az ín elcsúszásában, illetve csökkent összenövéseket, összehasonlítva, amikor mindkét (flexor digitorum profundus [FDP] és flexor digitorum superficialis [FDS]) inat megvarrták [17-19]. Csak az egyik FDSszár reszekciója megkönnyítette a helyreállított ín elcsúszását [18, 20].

Tang [18] vizsgálatai szerint, ha az ínvarrat az $\mathrm{A}_{2}$ pulley területére esik, javasolt bemetszeni a pulley egy részét és/vagy reszekálni az FDS-ín egyik szárát, hogy megóvjuk a szúk térben történő összezsúfolódástól a képleteket az $\mathrm{A}_{2}$ pulley-n belül, amelyet minden bizonnyal súlyosbít az ín posztoperatív ödémája is. Ezek a fontos részletek újabban fokozottan hangsúlyozásra kerültek a jobb klinikai végeredmény megvalósítása céljából úgy a primer, mint a szekunder ínhelyreállítás esetében [21, 22].

\section{Az öltések száma}

In vitro tanulmányokban igazolódott és már széles körben elfogadott, hogy a varratok öltésszámának megnövelése az ínsérülés helyén arányosan csökkenti a résképződést [23]. Jelenleg a 2 öltéses ínvarratot a szerzők többsége nem javasolja a nem megfelelő mechanikai szakítószilárdsága miatt, mivel legtöbbször nem képes biztonsággal elviselni az aktív mozgatást a mútét utáni reha- bilitációs gyakorlatok során. A 4 öltéses varrattechnika megfelelő szakítószilárdságot biztosít és - az esetek többségében - könnyú kivitelezni [24]. Jelenleg a leggyakrabban alkalmazott technikának számít, amelyet a digitális hajlítóinak helyreállításában használnak [25].

\section{Varróanyagok}

Ami a varróanyagok tulajdonságait illeti, az ideális varratnak magas szakítószilárdsággal és könnyű kezelhetőséggel, továbbá a lehetséges legkisebb szöveti reakcióval kell rendelkeznie. Jelenleg nincs egyetértés az ínhelyreállításban használatos varróanyagok terén, és hogy a sebészek melyiket részesítik előnyben inkább egyéni tapasztalatokon alapul, mintsem tudományos bizonyítékon. A gyakrabban használtak: Ethibond, Ethilon, Supramid, Prolene; növekvő népszerüségü a FiberWire varróanyag; jelenleg kevéssé használatosak a felszívódó PDS és Maxon nevü termékek.

A FiberWire multifil, polietilén varróanyag, amelyet az elmúlt tíz évben egyre növekvő számban használnak ínvarratok céljára. In vitro vizsgálatok azt mutatták, hogy ez a termék szignifikánsan erősebb, mint az Ethibond, a Prolen vagy a nylon varróanyag, de még a - több hátránynyal rendelkező - acéldrótnál is [26]. A FiberWire varróanyag azonban vastagabb átmérőjü, mint a hasonló szakítási erejű termékek. Ha a szakítási szilárdságot összehasonlítjuk az azonos keresztmetszettel, akkor a fenti termék már csak 10\%-kal erősebb, mint a Prolene és 25\%-kal, mint a Ticron [27]. Ehhez hozzá kell vennünk, hogy a csomók ínszövetben történő tartása gyakran nem kielégítő; ezt a varróanyag felrostozódása okozza, ezért több csomót kell alkalmaznunk, hogy megelőzzük a csomók felbomlását [28].

Nikkel-titánium (NiTi) drót kitűnő szakítószilárdsággal és megfelelő merevséggel rendelkezik, jó, szuper elasztikus tulajdonsággal és könnyű kezelhetőséggel; a közlések szerint sokat ígérô, új fémvarrat lehet az ínhelyreállításban. Intratendinealis és körkörös varratot javasoltak $200 \mu \mathrm{m}$ és $100 \mu \mathrm{m}$ drótvastagságban. Mindazonáltal in vivo vizsgálatok szükségesek még a klinikai felhasználás előtt [29].

Felszívódó varróanyagok (például a Maxon és a polidioxanon [PDS]), a vizsgálatok szerint, kielégítő szakítószilárdságot mutattak az aktív ínmobilizációval szemben 
[30]. Caulfield és mtsai [31] kimutatták, hogy a fenti felszívódó varratok kitúnő vagy jó eredményt adtak, öszszehasonlítva a nem felszívódó termékekkel. Azonban hosszabb távon kimutatott csökkent szakítószilárdságuk és a nagyobb fokú elaszticitásuk gátolhatják a szélesebb körű klinikai felhasználásukat [6].

$\mathrm{Az}$ intratendinealis varratok átmérôjét tekintve ez ideig 2-0, 3-0, 4-0 és 5-0 jelölésű varróanyagokat alkalmaztak ínvarratok céljára; ezek közül a 3-0 és 4-0-s anyagok voltak a leginkább használatosak [22]. A 2-0-s varróanyagot ritkábban használják, mivel az ínban jelentősebb csomóképződést hoz létre a varrat helyén, az 5-0-s pedig nem kielégítő szakítószilárdsággal rendelkezik [6].

A varrat lényeges eleme a csomó megkötése, amely jelentős befolyással bír az ínvarrat szilárdságára. A hajlítóínvarrat elszakadása rendszerint a csomó területén jön létre, amely ilyen formán a varrat leggyengébb pontjának tekinthető. A varrat csomója elhelyezkedésének hatását az ínvarrat szakítószilárdságára több szerző vizsgálta. Aoki és mtsai [32] javasolták, hogy csomók az ínon történt helyreállítás helyétől, az ínfelszíntől távolabbra kerüljenek, amennyire csak lehetséges. Azonban in vivo körülmények között az ínsértés helyén elhelyezkedő varróanyag nem bizonyult károsnak a szakítószilárdságra, és stimulálóhatást gyakorolt az íngyógyulásra [33]. A csomók száma bizonyítottan megváltoztatja az ínvarrat szakítószilárdságát in vitro. Általában háromszoros megcsomózás szükséges, hogy egy csomó szilárdan rögzítsen; ha FiberWire-t használunk, akkor ennél több [28].

\section{Az epitenonvarratok}

Amikor az intratendinealis öltések mellett epitendinosus (újabban perifériásnak nevezett) varratokat is alkalmaztak, megfigyelték, hogy a helyreállított ín szakítószilárdsága megnövekedett és csökkent a résképződés az ínvégek között, továbbá javult az ín csúszóképessége az ínhüvelyen belül. E varrattechnikát az 1980-as és 1990es években fejlesztették ki [6].

Az ideális perifériás varrat csak kisfokú elcsúszási súrlódást fejt ki az ín és a környező szövetek között. Jelenleg az egyszerú, tovafutó epitenonvarrat maradt meg széles körben használatos (9. ábra), valószínúleg azért, mivel a többi varrattechnika használatát a klinikai gyakorlatban korlátozza bonyolult kivitelezhetőségük [25].

A perifériás öltések mélységbeli elhelyezése és az ínszövetben történő rögzülése szignifikánsan befolyásolja a varrott ín szakítószilárdságát. Mélyre terjedő perifériás varratok és a perifériás öltések megnövelt távolsága a varrott íncsonktól szignifikánsan nagyobb átlagterhelhetőséget mutatott [34].

\section{Az intratendinealis varratok rögzülése}

Az ín központi részében elhelyezkedő (intratendinealis) varrat szilárdságának (ínszövetben történő tartásának) hatását úgy mérték le, hogy a mobilizáció során mennyi

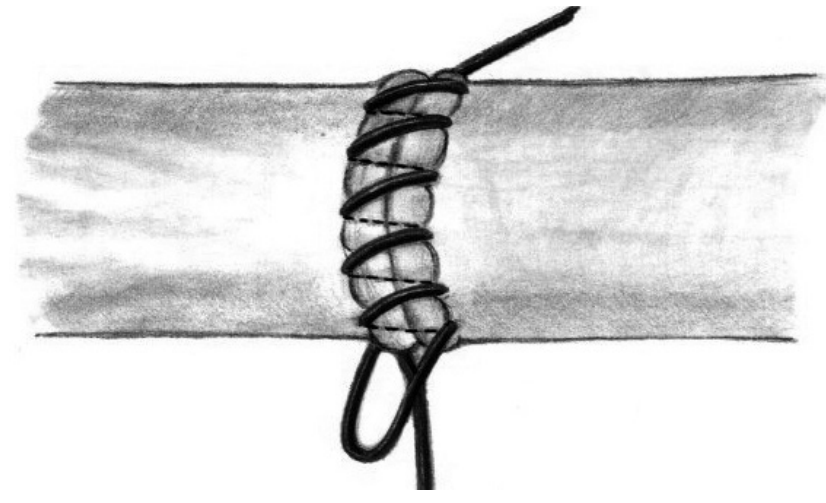

9. ábra | A körkörös, tovafutó epitenonvarrat ábrázolása [3]

hézag jött létre a varratok behelyezési helye és az átvágott ínvégek között. Ezt elsőként, kísérletes körülmények között, ferdén átvágott inakon tanulmányozták [35]; ezt követően pedig vizsgálták a harántul sértett inak varratát, hasonló csoportban [24]. A varratnak az ínban lévő hosszát vizsgálva, az idézett szerzők azt találták, hogy a leginkább optimális tartás a harántöltéseknek az ínvégektôl 7-10 mm-re elhelyezett varrataitól várhatók. Tang [36] hangsúlyozta, hogy az intratendinealis öltésben létrehozott mérsékelt feszülés előnyös az izomhúzás ellenállásának legyőzése céljából, és csökkenti a varratvonalban kialakuló résképződést a korai mozgatás alatt. Az íncsonkok között kialakult résképződés nem megfelelő íngyógyuláshoz, összenövésekhez, illetve az ínnak a pulley-khez történő megakadásához vezet. Ha megfelelő feszülést hozunk létre az ínvégek között a varratvonalban, ez megelőzi a résképződést a korai, aktív mozgatás idején [37]. A legkedvezőbb varróanyagnak a Prolene-öltések bizonyultak, az Ethibonddal szemben [38].

\section{A helyreállított ujj mozgásívének jelentősége}

Az ínvarrat feszülésének iránya és az ín mozgásának íve megváltozik az ínhelyreállító mütét után. A résképződést kialakító erő és a végső szakítószilárdság fokozatosan csökken az ujj mozgásában $0^{\circ}$-ról 90-ra [39]. Az ín mozgásirányának lecsökkent szöge az ínvarrat szakítószilárdságát jelentősen csökkenti [40]. Ez a két jelenség fontosnak ítélhető meg a klinikai gyakorlatban, amikor a varrott ín csúszásra kényszerül az ínhüvely, a gyürüszalagok és az ízületek felett. Az ujj fokozatos hajlítása során az ínvarrat területe meggyengülhet. Emiatt $W u$ és Tang [6] javasolják, hogy a korai, aktív ujjhajlításnál ne eróltessék a teljes, digitális hajlítási ív kétharmadánál nagyobb flexiót a műtétet követő három hétig, pontosabban a mütét utáni 1-2. héten a teljes mozgási tartománynak csupán egyharmadáig, feléig végezzenek hajlítási gyakorlatokat. 


\section{Következtetések}

Az ínvarrattechnika területén a fejlődés az elmúlt másfél évtizedben tovább folytatódott. A legjelentősebb klinikai változás e periódusban a több öltésből álló intratendinealis varratok alkalmazása volt. A szerzők többsége javasolja a legalább 4 öltéses intratendinealis ínvarrat használatát (3-0 vagy 4-0 méretben), az átmetszett flexor digitorum profundus ínon. Az intratendinealis varrat egyedüli elvégzése újabb fejleményt jelent. Amennyiben perifériás (körkörös) varratokat nem végzünk az intratendinealis technika mellett, a 6 öltéses varratot javasolják, oly módon, hogy e varratokkal az ínvégek között mérsékelt feszülést hoznak létre [6].

A dolgozatunkban ismertetett vizsgálatok nagyobb részét mindeddig cadaveren vagy állatkísérletekben végezték. E tanulmányokat rövid időn belül követnie kellene az eddigieknél nagyobb számú in vivo vizsgálatoknak, illetve betegeken történő klinikai alkalmazásnak, hogy a kézsebészet e fontos részterületéről jóval teljesebb körü értékelést kaphassunk. Ez - minden bizonnyal - a közeljövő feladatát fogja képezni.

Anyagi támogatás: A közlemény megírása anyagi támogatásban nem részesült.

A cikk végleges változatát a szerző elolvasta és jóváhagyta.

Érdekeltségek: A szerzőnek nincsenek érdekeltségei.

\section{Köszönetnyilvánítás}

A szerző köszönetét fejezi ki menyének, Schanzl Ágnesnek (Pécs) az l., 2. és 4. ábra elkészítésében nyújtott segítségéért.

\section{Irodalom}

[1] Bíró, V.: Changes of therapy guidelines in flexor tendon hand surgery. [A terápiás irányelvek változása a kéz hajlítóin sebészetében.] Magyar Traumatológia, Ortopédia, Kézsebészet, Plasztikai Sebészet, 2011, 54(1), 3-11. [Hungarian]

[2] Biró, V.: Flexor tendon surgery: advances in the field of hand surgery. [Hajlítóín-sebészet - a kézsebészet egyik fontos részterületének fejlődése.] Orv. Hetil., 2012, 153(21), 811-820. [Hungarian]

[3] Bíró, V., Nyárády, J.: Hand injuries. Illustrated pocket book for emergency care. [Kézsérülések ügyeletben. A sürgősségi ellátás képes zsebkönyve.] Medicina Könyvkiadó, Budapest, 2013. [Hungarian]

[4] Kós, R.: Treatment of flexor tendon injuries of the hand. In: Kós, R.: Hand surgery. [A kéz sérült hajlítóinainak kezelése. In: Kós, R.: A kéz sebészete.] Medicina Kiadó, Budapest, 1961. [Hungarian]

[5] Sántha, E.: Injuries and diseases of flexor tendons. In: Renner A., Sántha, E.: (eds.): Hand surgery. [A hajlítóinak sérülései és betegségei. In: Renner, A., Sántha, E.: A kéz sebészete.] Kadix Press Kiadó, Budapest, 2014. [Hungarian]

[6] Wu, Y. F., Tang, J. B.: Recent developments in flexor tendon repair techniques and factors influencing strength of the tendon repair. J. Hand Surg. Eur. Vol., 2014, 39(1), 6-19.
[7] Wang, B., Xie, R. G., Tang, J. B.: Biomechanical analysis of a modification of Tang method of tendon repair. J. Hand Surg. Br., 2003, 28(4), 347-350.

[8] Tang, J. B., Shi, D., Gu, Y. Q., et al.: Double and multiple looped suture tendon repair. J. Hand Surg. Br., 1994, 19(6), 699-703.

[9] Manchio, J. V., Shashikant, M. P., Shrivastava, A., et al.: Evaluation of a new 4 -strand flexor tendon repair in a cadaveric porcine model. J. Hand Surg. Am., 2009, 34(1), 102-107.

[10] Osada, D., Fujita, S., Tamai, K., et al.: Flexor tendon repair in zone II with 6-strand techniques and early active mobilization. J. Hand Surg. Am., 2006, 31(6), 987-992.

[11] Hoffmann, G. L., Büchler, U., Vögelin, E.: Clinical results of flexor tendon repair in zone II using a six-strand double-loop technique compared with a two-strand technique. J. Hand Surg. Eur. Vol., 2008, 33(4), 418-423.

[12] Su, B. W., Protopsaltis, T. S., Koff, M. F., et al.: The biomechanical analysis of a tendon fixation device for flexor tendon repair. J. Hand Surg. Am., 2005, 30(2), 237-245.

[13] Su, B. W., Raia, F. J., Quitkin, H. M., et al.: Gross and histological analysis of healing after dog flexor tendon repair with the Teno Fix device. J. Hand Surg. Br., 2006, 31(5), 524-529.

[14] Wolfe, S. W., Willis, A. A., Campbell, D., et al.: Biomechanic comparison of the Teno Fix tendon repair device with the cruciate and modified Kessler techniques. J. Hand Surg. Am., 2007, 32(3), 356-366.

[15] Su, B. W., Solomons, M., Barrow, A., et al.: Device for zone-II flexor tendon repair. A multicenter, randomized, blinded, clinical trial. J. Bone Joint Surg. Am., 2005, 87(5), 923-935.

[16] Rocchi, L., Merolli, A., Genzini, A., et al.: Flexor tendon injuries of the hand treated with TenoFix: mid-term results. J. Orthop. Traumatol., 2008, 9(4), 201-208.

[17] Tang, J. B., Xu, Y., Chen, F.: Impact of flexor digitorum superficialis on gliding function of the flexor digitorum profundus according to regions in zone II. J. Hand Surg. Am., 2003, 28(5), 838-844.

[18] Tang, J. B., Xie, R. G., Cao, Y., et al.: A2 pulley incision or one slip of the superficialis improves flexor tendon repairs. Clin. Orthop. Relat. Res., 2007, 456, 121-127.

[19] Xu, Ү., Tang, J. B.: Effects of superficialis tendon repairs on lacerated profundus tendons within or proximal to the A2 pulley: an in vivo study in chickens. J. Hand Surg. Am., 2003, 28(6), 9941001 .

[20] Zhao, C., Amadio, P. C., Zobitz, M. E., et al.: Resection of the flexor digitorum superficialis reduces gliding resistance after zone II flexor digitorum profundus repair in vitro. J. Hand Surg. Am., 2002, 27(2), 316-321.

[21] Elliot, D., Giesen, T.: Primary flexor tendon surgery: The search for a perfect result. Hand Clin., 2013, 29(2), 191-206.

[22] Tang, J. B.: Outcomes and evaluation of flexor tendon repair. Hand Clin., 2013, 29(2), 251-259.

[23] Barrie, K. A., Tomak, S. L., Cholewicki, J., et al.: The role of multiple strands and locking sutures on gap formation of flexor tendon repairs during cyclical loading. J. Hand Surg. Am., 2000, 25(4), 714-720.

[24] Cao, Y., Tang, J. B.: Strength of tendon repair decreases in the presence of an intact A2 pulley: biomechanical study in a chicken model. J. Hand Surg. Am., 2009, 34(10), 1763-1770.

[25] Tang, J. B., Amadio, P. C., Boyer, M. I., et al.: Current practice of primary flexor tendon repair: a global view. Hand Clin., 2013, 29(2), 179-189.

[26] McDonald, E., Gordon, J. A., Buckley, J. M., et al.: Comparison of a multifilament stainless steel suture with FiberWire for flexor tendon repairs - an in vitro biomechanical study. J. Hand Surg. Eur. Vol., 2013, 38(4), 418-423.

[27] Scherman, P., Haddad, R., Scougall, P., et al.: Cross-section area and strength differences of FiberWire, Prolene and Ticron sutures. J. Hand Surg. Am., 2010, 35(5), 780-784. 
[28] Le, S. V., Chin, S., Meineke, R. C., et al.: Number of suture throws and its impact on the biomechanical properties of the four-strand cruciate locked flexor tendon repair with FiberWire. J. Hand Surg. Eur. Vol., 2012, 37(9), 826-831.

[29] Karjalainen, T., Göransson, H., Viinikainen, A. J., et al.: Nickeltitanium wire as a flexor tendon suture material: an ex vivo study. J. Hand Surg. Eur. Vol., 2010, 35(6), 469-474.

[30] Wada, A., Kubota, H., Akiyama, T., et al.: Effect of absorbable polydioxanone flexor tendon repair and restricted active mobilization in a canine model. J. Hand Surg. Am., 2001, 26(3), 398406.

[31] Caulfield, R. H., Maleki-Tabrizi, A., Patel, H., et al.: Comparison of zones 1 to 4 flexor tendon repairs using absorbable and unabsorbable four-strand core sutures. J. Hand Surg. Eur. Vol., 2008, $33(4), 412-417$.

[32] Aoki, M., Pruitt, D. L., Kubota, H., et al.: Effect of suture knots on tensile strength of repaired canine flexor tendons. J. Hand Surg. Br., 1995, 20(1), 72-75.

[33] Pruitt, D. L., Aoki, M., Manske, P. R.: Effect of suture knot location on tensile strength after flexor tendon repair. J. Hand Surg. Am., 1996, 21(6), 969-973.

[34] Merrell, G. A., Wolfe, S. W., Kacena, W. J., et al.: The effect of increased peripheral suture purchase on the strength of flexor tendon repairs. J. Hand Surg. Am., 2003, 28(3), 464-468.
[35] Tan, J., Tang, J. B.: Locking repairs for obliquely cut tendons: Effects of suture purchase and directions of locking circles. J. Hand Surg. Am., 2004, 29(5), 891-897.

[36] Tang, J. B.: Indications, methods, postoperative motion and outcome evaluation of primary flexor tendon repairs in Zone 2. J. Hand Surg. Eur. Vol., 2007, 32(2), 118-129.

[37] Lalonde, D. H., Martin, A. L.: Wide-awake flexor tendon repair and early tendon mobilization in zones 1 and 2. Hand Clin., 2013, 29(2), 207-213.

[38] Smith, G. H., Huntley, J. S., Anakwe, R. E., et al.: Tensioning of Prolene reduces creep under cyclical load: relevance to a simple pre-operative manoeuvre. J. Hand Surg. Eur. Vol., 2012, 37(9), 823-825

[39] Tang, J. B., Cao, Ү., Xie, R. G.: Effects of tension direction on strength of tendon repair. J. Hand Surg. Am., 2001, 26(6), 1105-1110.

[40] Tang, J. B., Xu, Y., Wang, B.: Repair strength of tendons of varying gliding curvature: a study in a curvilinear model. J. Hand Surg. Am. 2003, 28(2), 243-249.

(Bíró Vilmos dr., Pécs, Hajnóczy u. 25/A, II. em. 2., 7633 e-mail: biro.vilmos2@chello.hu)

\section{Pályázati felhívás}

Professzor Dr. Fehér János munkássága, szakmai és erkölcsi hagyatéka páratlan és maradandó az orvostudományban. Ezért a Semmelweis Egyetem Általános Orvostudományi Kar II. sz. Belgyógyászati Klinika volt igazgatója, „A hepatológiai szabad gyökös és immunológiai vonatkozásai" című program vezetőjének, az Orvosi Hetilap főszerkesztőjének emlékére Alapítvány létesült. Az alapítványt a Fővárosi Bíróság 2011. március 7-én 11.335. sorszám alatt nyilvántartásba vette.

Dr. Fehér János Emlékére Alapítvány fő célja: a belgyógyászat, különösen a hepatológia szabad gyökös és immunológiai vonatkozásai témakörök kutatásának fejlesztése, támogatása, illetve ösztönzése oly módon, hogy a fiatal egyetemi oktatók és hallgatók az alapítvány kamatából részesüljenek. Az alapítvány célja olyan orvosok, PhD-hallgatók díjazása, akik kiemelkedő tudományos munkát végeznek és eredményeiket az Orvosi Hetilapban publikálják.

A dolgozatot „Dr. Fehér János pályázat” megjelölésével kell benyújtani.

A pályázatot 2016. április 5-ig lehet beküldeni a Kuratórium elnökének (Dr. Rácz Károly) vagy titkárának (Dr. Lengyel Gabriella) - Semmelweis Egyetem, II. sz. Belgyógyászati Klinika, 1088 Budapest, Szentkirályi u. 46. címre.

A pályázathoz mellékelni kell a pályázó önéletrajzát és a dolgozatot.

A dijjak odaítéléséröl a kuratórium dönt. A dij átadására a Markusovszky ünnepségen kerül sor. Az ünnepségen a nyertes pályázó maximum 5-10 perces előadásban foglalja össze az eredményeit. 